\title{
Regulation of chitin synthesis during dimorphic growth of Candida albicans
}

\author{
C. A. Munro, D. A. Schofield, †. W. Gooday and N. A. R. Gow \\ Author for correspondence: N. A. R. Gow. Tel: +44 1224 273179. Fax: +44 1224273144. \\ e-mail: n.gow@abdn.ac.uk
}

Department of Molecular $\&$ Cell Biology, Institute of Medical Sciences,

University of Aberdeen,

Aberdeen AB25 2ZD, UK

\begin{abstract}
Candida albicans has three genes encoding chitin synthase enzymes. In wildtype strains, the expression of CHS2 and CHS3 peaked 1-2 $\mathrm{h}$ after the induction of hyphal growth, whilst mRNA levels in a non-germinative strain, CA2, remained low under the same conditions. CHS1 gene expression did not peak during germ tube formation but remained at low levels in both yeast and hyphal growth. The pattern of gene expression did not predict the changes in measured chitin synthase activities or changes in chitin content during dimorphic transition. Chitin synthase activity increased steadily, and did not peak shortly after germ tube induction, and activity profiles were similar in germ-tube-competent and germ-tube-negative strains. The phenotype of a $\Delta$ chs2 null mutant suggested that CHS2 encoded the major enzyme activity in vitro and was largely responsible for elevated chitin synthase activities in microsomal preparations from hyphal cells compared to yeast cells. However, CaChs3p was responsible for synthesis of most chitin in both yeast and hyphae. Three independent chitin assays gave markedly different estimates of the relative chitin content of yeast and hyphae and wild-type and chs mutants. Only one of the methods gave a significantly higher chitin content for hyphal compared to yeast cell walls and a lower chitin content for hyphae of the $\Delta c h s 2$ null mutant compared to the parental strain.
\end{abstract}

Keywords: Candida albicans, dimorphism, gene expression, chitin synthase, chitin

\section{INTRODUCTION}

Chitin synthase isoenzymes of fungi catalyse the synthesis of the structural polysaccharide chitin, the (1-4)$\beta$-homopolymer of $\mathrm{N}$-acetylglucosamine that is important for cell shape, strength and viability (Bulawa, 1993; Shaw et al., 1991; Yarden \& Yanofsky, 1991). The hyphal cell walls of the dimorphic human pathogenic fungus Candida albicans have been reported to have a higher chitin content than yeast cell walls (Chattaway et al., 1968; Elorza et al., 1994; Sullivan et al., 1983) and the specific chitin synthase activity of hyphae has been estimated to be twice that of yeast cells (Braun \& Calderone, 1978). Therefore, chitin synthesis in C. albicans is regulated in a temporal and spatial manner. The study of chitin synthesis is relevant not only to our understanding of fungal growth and morphogenesis but

† Present address: School of Biological Sciences, 2.205 Stopford Building, Oxford Road, University of Manchester, Manchester M13 9PT, UK.

Abbreviation: MMF, mixed membrane fraction. also in relation to its potential as a target for antifungal drugs. The enzyme chitin synthase is common to all fungi but has not been found in mammalian cells, although an enzyme that is capable of synthesizing short chitin oligosaccharides has recently been described in Xenopus (Semino \& Robbins, 1995).

The study of chitin synthesis is most advanced in Saccharomyces cerevisiae, where genes for three chitin synthase isoenzymes have been characterized (reviewed by Bulawa, 1993). There is no evidence for functional redundancy of chitin synthase isoenzymes in S. cerevisiae - targeted gene disruption experiments suggest that each isoenzyme performs a separate role and functions at a distinct stage of the cell cycle. ScChs1p is the major activity in vitro yet $\Delta c h s 1$ mutants have only a subtle phenotype of bud lysis under certain conditions. The ScChs1p is thought to be involved in cell wall repair following chitinase-mediated release of the daughter bud (Bulawa et al., 1986; Cabib et al., 1989, 1992). ScChs2p synthesizes chitin of the primary septal plate (Bulawa \& Osmond, 1990; Silverman et al., 1988; Shaw 
et al., 1991) while ScChs3p is responsible for the bulk of chitin production in both the lateral cell wall and at the chitin ring that marks the site of new bud development and eventually gives rise to the bud scar (Bulawa, 1992; Shaw et al., 1991; Valdivieso et al., 1991). The functional role of the chitin synthase enzymes in S. cerevisiae is also supported by immunocytochemical studies. The ScChs$2 p$ was found at the neck of buds at late mitosis while the ScChs3 $\mathrm{p}$ formed a surface ring in pre- and post-budded cells (Chuang \& Schekman, 1996).

C. albicans also has three chitin synthase genes,

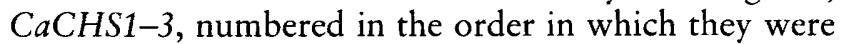
isolated (Au-Young \& Robbins, 1990; Chen-Wu et al., 1992; Sudoh et al., 1993). The CaCHS1 and CaCHS2 genes belong to classes II and I, respectively, as defined by Bowen et al. (1992). The two gene products are apparently zymogenic and are activated in vitro by proteolysis. The CaCHS3 gene is a class IV enzyme (Din et al., 1996) and until recently enzymes in this class were thought to be non-zymogenic. However, the ScCHS3 gene product is activated by proteases if the substrate UDP- $N$-acetylglucosamine is used to protect the enzyme from proteolysis during its isolation (Choi et al., 1994b).

Although CaChs1p has a $\mathrm{pH}$ optimum similar to ScChs1p (Au-Young \& Robbins, 1990), it is more similar at the amino acid level to the predicted ScChs2p. Reciprocally, CaCHS2 is more similar to ScCHS1 at the predicted amino acid level and is shown here to encode the major chitin synthase activity when assayed in vitro. It is likely that the CHS1 gene of C. albicans is the functional homologue of ScCHS2 which is involved in the synthesis of the chitin plate in the primary septum (Mio et al., 1996; C. A. Munro, K. Winter, C. E. Bulawa, A. J. P. Brown \& N. A. R. Gow, unpublished). The activation and regulation of the chitin synthase enzymes in vivo is not well understood.

Preliminary reports based on very limited Northern analyses suggest that $\mathrm{CaCHS} 2$ and $\mathrm{CaCHS} 3$ are expressed preferentially in the hyphal phase of growth whilst $\mathrm{CaCHS1}$ appears to be expressed at a low level in both yeast and hyphae (Chen-Wu et al., 1992; Sudoh et al., 1993). Here we extend these studies and show that CHS gene expression is regulated differentially during yeast/hypha transitions induced by a wide variety of culture conditions that support filamentous growth.

Characterization of the role of Candida chitin synthase isoenzymes has employed the Ura-blaster technique to disrupt the CaCHS2 (Gow et al., 1994) and the $\mathrm{CaCHS} 3$ (Bulawa et al., 1995) genes. Neither of these genes was found to be essential and both null mutants were able to produce hyphae. The $\Delta c h s 3$ null mutant was characterized by an approximate $80 \%$ reduction in cell wall chitin compared to the parental strain (Bulawa et al., 1995). Historically, a variety of different methods have been used to measure the chitin content of chitin synthase mutants, making it difficult to compare the data from different laboratories. One discrepancy between the different studies has been the chitin content of the $\Delta c h s 2$ null mutant. Gow et al. (1994) reported a $40 \%$ reduction in the chitin content of the hyphal form of a $\Delta c h s 2$ null mutant whereas Mio et al. (1996) found the chitin content to be similar to that of the parental strain. We address this discrepancy and report here that chitin contents determined by different methods yield markedly different results that can account for the apparent discrepancies in the literature.

\section{METHODS}

Strains and mutants. Invasive clinical isolates of C. albicans, $\mathrm{Ca} 94$ and $\mathrm{Ca} 30$, and non-invasive isolates $\mathrm{Ca} 88$ and $\mathrm{Ca} 89$ were supplied by Dr G. Cole, University of Texas, Austin, TX (Cole et al., 1990). C. albicans (Robin) Berkhout, strain 3153, was obtained from the Mycological Reference Collection (formerly at Colindale, London, now at Department of Microbiology, University of Leeds). C. albicans CA2 was supplied by Professor A. Cassone, Instituto Superiore di Sanita, Rome. The CA2 strain does not produce germ tubes under conditions that normally induce germ tube production in vitro but forms true, unconstricted hyphae in vaginitis infection models (De Bernardis et al., 1993). The Ura ${ }^{-}$strain C. albicans SGY243 was a gift from R. Kelly (Kelly et al., 1987). NGY2 and NGY4 are heterozygous $\Delta c h s 2$ null mutants with one or two disrupted copies of CaCHS2 and NGY10 is a homozygous $\Delta c h s 2$ null mutant (Gow et al., 1994). All were constructed from the parental Ura- strain SGY243 (Table 1). The $\Delta$ chs 3 mutant Myco3 was supplied by C. Bulawa (Bulawa et al., 1995).

Culture conditions for yeast and hyphal growth. Yeast cells of C. albicans were grown in the medium described by Buffo et al. (1984) as modified from Lee et al. (1975) adjusted to $\mathrm{pH} 4.5$ and incubated at $25^{\circ} \mathrm{C}$. Hyphal growth occurred in the same medium at $\mathrm{pH} 6.5$ and $37^{\circ} \mathrm{C}$. For cell-density-dependent dimorphic regulation, stationary phase yeast cells were grown in this medium at $\mathrm{pH} 4.5$ and $25^{\circ} \mathrm{C}$ and were then inoculated into fresh medium at $\mathrm{pH} 6.5$ and $37^{\circ} \mathrm{C}$ at an inoculum density of $2 \times 10^{7}$ cells $\mathrm{ml}^{-1}$ (low density for hyphal growth) or $\geqslant 1 \times 10^{8}$ cells $\mathrm{ml}^{-1}$ (high density for yeast growth). Hyphal growth was also induced by resuspending yeast cells grown in YPD (Sherman, 1991) in 10 vols pre-warmed $5 \%$ newborn calf serum (Gow \& Gooday, 1982) or in $2.5 \mathrm{mM} \mathrm{N}$-acetylglucosamine containing $0.01 \mathrm{mM}$ imidazole $/ \mathrm{HCl}$ buffer $(\mathrm{pH}$ 6.6) and $0.1 \mathrm{mM} \mathrm{MnSO}{ }_{4}$ (Simonetti et al., 1974) and incubating at $37^{\circ} \mathrm{C}$. In all experiments, germ tube formation was monitored using a light microscope and cell density was measured spectrophotometrically at $600 \mathrm{~nm}$ (LKB-Ultrospec II model 4050 spectrophotometer).

RNA extraction and Northern blot analysis. C. albicans cells were harvested at the various time-points by centrifugation and cell pellets were stored at $-70^{\circ} \mathrm{C}$. Total RNA was extracted from the cells and Northern blots were prepared by the method of Hube et al. (1994). No suitable internal loading standard has been identified for Northern analysis of $C$. albicans mRNA during germ tube formation (Delbruck \& Ernst, 1993; Swoboda et al., 1994; Gow et al., 1995). Therefore, equal loading was confirmed by examining the density of ethidium-bromide-stained rRNA bands. Sizes of CHS transcripts were estimated by assuming that the $C$. albicans rRNA transcripts were of similar sizes to the $S$. cerevisiae $18 \mathrm{~S}$ and $26 \mathrm{~S}$ rRNA bands, which are 1789 (Rubtsov et al., 1980) and 3392 (Georgiev et al., 1981) nucleotides, respectively. 
Table 1. C. albicans strains

\begin{tabular}{|c|c|c|}
\hline Strain & Genotype & Reference \\
\hline SGY243 & ade2/ade2, $\triangle$ ura $3:: A D E 2 / \Delta u r a 3:: A D E 2, C H S 2 / C H S 2 / C H S 2$ & Kelly et al. (1987) \\
\hline NGY2 & ade2/ade2, $\Delta u r a 3:: A D E 2 / \Delta u r a 3:: A D E 2, \Delta c h s 2::$ hisG/CHS2/CHS2 & Gow et al. (1994) \\
\hline NGY4 & ade2/ade2, $\Delta u r a 3:: A D E 2 / \Delta u r a 3:: A D E 2, \Delta c h s 2::$ his $G / \Delta c h s 2:: b i s G / C H S 2$ & Gow et al. (1994) \\
\hline NGY10 & 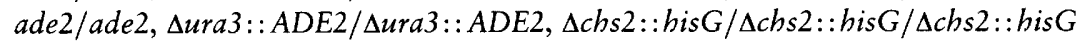 & Gow et al. (1994) \\
\hline$\Delta c h s 3$ & 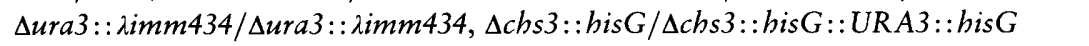 & Bulawa et al. (1995) \\
\hline
\end{tabular}

The Northern blot membranes were pre-hybridized overnight in $50 \%(\mathrm{v} / \mathrm{v})$ formamide, $0.5 \%(\mathrm{w} / \mathrm{v}) \mathrm{SDS}, 5 \times$ SSC and $5 \times$ Denhardt's solution at $42{ }^{\circ} \mathrm{C}$. Denatured salmon sperm DNA was added at a final concentration of $100 \mu \mathrm{g} \mathrm{ml}^{-1}$. Probe DNA was labelled with $50 \mu \mathrm{Ci}(1.85 \mathrm{MBq})\left[\alpha^{-32} \mathrm{P}\right] \mathrm{dCTP}$ by the Random Primed Labelling kit (Boehringer). After at least $16 \mathrm{~h}$ incubation, membranes were washed twice in a solution containing $2 \times \mathrm{SSC}$ and $0.1 \%(\mathrm{w} / \mathrm{v})$ SDS for $5 \mathrm{~min}$ at $20^{\circ} \mathrm{C}$ followed by $20 \mathrm{~min}$ at $42{ }^{\circ} \mathrm{C}$. They were then washed with $2 \times$ SSC, $0.1 \%(\mathrm{w} / \mathrm{v}) \mathrm{SDS}$ for $20 \mathrm{~min}$ at $55^{\circ} \mathrm{C}$ and finally twice with $0.2 \times$ SSC, $0.5 \%(\mathrm{w} / \mathrm{v})$ SDS for $20 \mathrm{~min}$ at $55^{\circ} \mathrm{C}$. The expression levels of the CHS genes were low and membranes were normally exposed to Fuji medical X-ray film for up to $6 \mathrm{~d}$. In each case, the membranes were stripped and hybridized with each of the three $\mathrm{CaCHS}$-gene-specific probes.

Purification of DNA probes for Northern blot analysis. Plasmid pJA16 was kindly provided by $\mathrm{Dr}$ J. Au-Young (AuYoung \& Robbins, 1990) and contained the CaCHS1 gene located in the vector YEp351 (Hill et al., 1986). A CaCHS1specific probe was prepared by digesting plasmid pJA16 with Clal, which released a $1 \mathrm{~kb}$ fragment of the CaCHS1 ORF. The CaCHS2-specific probe was generated from plasmid pNG17 (Gow et al., 1994) by purification of a $1.7 \mathrm{~kb}$ HindIII fragment. A partial fragment of the CaCHS3 gene was generated by PCR. Primers 1 and 2 were constructed that were homologous to two regions at the $5^{\prime}$ end of the ORF of $\mathrm{CaCHS3}$. These primers were designed to include unique recognition sites for the restriction endonucleases $K p n I$ and Bam HI, respectively: primer 1 forward, 5' GTTTACACCATGGGGACTTC 3'; primer 2 reverse, 5' TTAGATGGATCCCAAGCAGC 3'.

These primers were employed to PCR-amplify a $1.24 \mathrm{~kb}$ fragment from $C$. albicans genomic DNA. The PCR product was gel-purified using the Prep-a-Gene kit (Bio-Rad) following the manufacturer's recommendations and was then cloned into pBluescript $\mathrm{SK}(-)$ (Stratagene) at the $K p n \mathrm{I}$ and $\mathrm{BamHI}$ sites to give plasmid pDAS. The identity of the cloned PCR product was confirmed by sequencing and Southern analysis. Plasmid pDAS was then digested with $K p n I$ and $B a m H I$ to release the insert, which was used as a $\mathrm{CaCHS3-specific} \mathrm{probe.}$

Measurement of chitin synthase activity. Yeast cells were grown on YPD at $30^{\circ} \mathrm{C}$ and harvested in late exponential phase. Germ tube formation was induced by inoculation into $20 \%(\mathrm{v} / \mathrm{v})$ newborn calf serum (Sigma) of $<2 \times 10^{7}$ stationary phase yeast cells $\mathrm{ml}^{-1}$ or by the cell-density-dependent conditions described above. After $6 \mathrm{~h}$ incubation with shaking at $37^{\circ} \mathrm{C}$, cells with germ tubes were harvested. Mixed membrane fractions (MMFs) were prepared by the method of Orlean (1987). Membrane pellets were resuspended in $50 \mathrm{mM}$ Tris $/ \mathrm{HCl}(\mathrm{pH} 7.5)$ supplemented with $30 \%(\mathrm{v} / \mathrm{v})$ glycerol and stored at $-20^{\circ} \mathrm{C}$. The protein concentration of each MMF preparation was determined using the Coomassie Protein Assay kit (Pierce).
Enzyme assays were performed with and without trypsin pretreatment. Activation with trypsin was optimized for each MMF preparation but standard trypsin pre-treatment used $100 \mathrm{ng}$ trypsin $(\mu \mathrm{l} \mathrm{MMF})^{-1}$ incubated for $5 \mathrm{~min}$ at $30^{\circ} \mathrm{C}$. Longer incubations resulted in loss of chitin synthase activity. Trypsin activation was stopped by addition of $150 \mathrm{ng}$ soybean trypsin inhibitor $(\mu \mathrm{l} M M F)^{-1}$. Standard reactions for measuring chitin synthase activity were carried out in $50 \mu \mathrm{l}$ volumes containing: $50 \mu \mathrm{g}$ MMF protein, $25 \mathrm{mM} \mathrm{N}$-acetylglucosamine, $50 \mathrm{mM}$ Tris $/ \mathrm{HCl}(\mathrm{pH} 7 \cdot 5), 10 \mathrm{mM} \mathrm{MgCl}$ and $1 \mathrm{mM}$ UDP- $N$-acetylglucosamine which included $25 \mathrm{nCi}(0.9 \mathrm{kBq})$ UDP-[U- $\left.{ }^{14} \mathrm{C}\right] \mathrm{N}$-acetylglucosamine. Reactions were carried out at $30^{\circ} \mathrm{C}$ for $30 \mathrm{~min}$ and then were stopped by addition of $1 \mathrm{ml}$ $66 \%(\mathrm{v} / \mathrm{v})$ ethanol. Reaction mixtures were then filtered through GF/C filter discs which had been pre-soaked in $10 \%$ $(\mathrm{v} / \mathrm{v})$ trichloroacetic acid and reaction tubes were rinsed out with $2 \times 1 \mathrm{ml} 1 \%(\mathrm{v} / \mathrm{v})$ Triton X-100. Each filter was then washed with $4 \times 2 \mathrm{ml} 66 \%(\mathrm{v} / \mathrm{v})$ ethanol, dried at $80^{\circ} \mathrm{C}$ and then placed in a vial for liquid scintillation counting. Results are expressed as units of chitin synthase activity. One unit represents $1 \mathrm{nmol}$ UDP- $N$-acetylglucosamine incorporated into chitin $\min ^{-1}$ (mg protein) ${ }^{-1}$.

Chitin measurements. Three different methods were used for chitin determinations. The method of Ride \& Drysdale (1972) combines an alkaline deacetylation to convert chitin to chitosan, and a nitrous acid treatment which depolymerizes and deaminates chitosan to the aldehyde 2,5-anhydromannose, which is measured colorimetrically. The second method involved acid hydrolysis of whole cells to break down chitin to glucosamine (Yabe et al., 1996). A third method involved the hydrolysis of chitin to $N$-acetylglucosamine by the action of chitinase (from Streptomyces griseus; supplied by Sigma) and $\beta$ - $N$-acetylhexosaminidase (a contaminant of Sigma $\beta$-glucuronidase $\mathrm{G}-1512$ ) and was based on the protocol of Bulawa et al. (1986) as modified by Mellado et al. (1996). C. albicans cells were grown in the yeast phase in YPD at $30^{\circ} \mathrm{C}$ or in the hyphal phase in $20 \%$ serum at $37^{\circ} \mathrm{C}$, each for $6 \mathrm{~h}$. For the first two methods, cells were freeze-dried to constant weight and the assays were performed on dried cells. For the third method (Bulawa et al., 1986), wet cells were used and a sample was freeze-dried so that results could be converted to dry weights.

\section{RESULTS}

\section{CHS expression in batch culture of the yeast form}

Invasive (Ca94 and Ca30) and non-invasive (Ca88 and Ca89) clinical isolates were grown in the yeast form in YPD medium and samples were harvested at various stages of growth. The general pattern of expression of the three CHS genes was qualitatively similar in all four 
strains although the level of transcription differed between strains (Fig. 1). Levels of expression of all three genes were highest in the mid exponential phase $5.5 \mathrm{~h}$ after inoculation into fresh media. CaCHS2 and $\mathrm{CaCHS} 3$ transcripts were detected at all the time-points tested but little or no $\mathrm{CaCHS1}$ message was detectable in the sample from the inoculum $(0 \mathrm{~h})$ and stationary phase (after $9 \mathrm{~h}$ ) of growth.

The influence of external $\mathrm{pH}$ on $\mathrm{CHS}$ gene expression was examined by growing yeast cells in yeast carbon base at a $\mathrm{pH}$ range of 3-7. As the external $\mathrm{pH}$ increased, the level of expression of all three chitin synthase genes increased and expression was highest in cells grown at pH 7 (data not shown).

\section{Levels of CHS mRNAs during the dimorphic transition}

Yeast cells of C. albicans were induced to form hyphae by $\mathrm{pH} /$ temperature shift (Buffo et al., 1984) and by inoculation into medium containing either $5 \%$ serum (Gow \& Gooday, 1982) or $25 \mathrm{mM} N$-acetylglucosamine (Simonetti et al., 1974). In $\mathrm{pH} /$ temperature-mediated dimorphism, growth of the yeast form is favoured at $\mathrm{pH} 4.5$ and $25^{\circ} \mathrm{C}$, at $\mathrm{pH} 6.5$ and $25^{\circ} \mathrm{C}$, and at $\mathrm{pH} 4.5$ and $37^{\circ} \mathrm{C}$, whilst hypha formation occurs at $\mathrm{pH} 6.5$ and $37^{\circ} \mathrm{C}$. CaCHS1 appeared to be expressed constitutively throughout both yeast and hyphal phases of growth (Fig. 2). In contrast, levels of $\mathrm{CaCHS2}$ and $\mathrm{CaCHS3}$ mRNA were high in exponentially growing yeast cells (5 or $6 \mathrm{~h}$ time-points) but rapidly decreased and expression increased transiently during hypha formation at $\mathrm{pH} 6.5$ and $37^{\circ} \mathrm{C}$. Highest levels of $\mathrm{CaCHS} 2$ and $\mathrm{CaCHS} 3$ mRNA were detected 1-2 $\mathrm{h}$ after inoculation into germtube-inducing media. A similar pattern of expression was also found when strain 3153 was induced to form germ tubes in the presence of serum or $\mathrm{N}$-acetylglucosamine (data not shown). CaCHS1 mRNA was undetectable in hyphal cells induced by $\mathrm{N}$-acetylglucosamine.

The dimorphic transition was also controlled by inoculum density in a manner similar to that described by Chen-Wu et al. (1992). A high inoculum density ( $1 \times 10^{8}$ cells $\mathrm{ml}^{-1}$ ) supported yeast growth with only $15 \%$ germ tubes present after $4 \mathrm{~h}$. In contrast, at a low inoculum density of $2 \times 10^{7}$ cells $\mathrm{ml}^{-1}, 81 \%$ hypha formation occurred by $4 \mathrm{~h}$. CaCHS1 mRNA was detected at low levels in the yeast phase and highest levels of expression of $\mathrm{CaCHS1}$ occurred when there were $81 \%$ germ tubes present (Fig. 3). CaCHS2 and $\mathrm{CaCHS} 3$ were expressed in both yeast and hyphal phases of growth but these peaked at a sustained high level during hypha formation (Fig. 3). The overall pattern of expression of the three genes was similar in all conditions supporting hypha development and differed significantly from control cultures grown at either the same external $\mathrm{pH}$ (Fig. 2) or temperature (Fig. 3), suggesting that changes in external $\mathrm{pH}$ and/or temperature were unlikely to explain the observed patterns of transcriptional regulation.

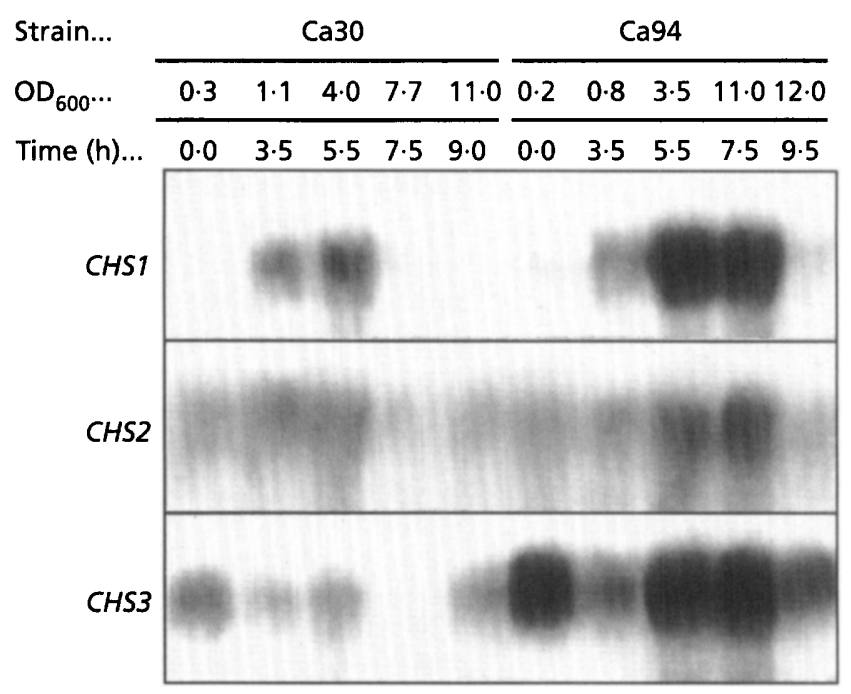

Fig. 1. Chitin synthase gene expression during growth in the yeast form of two invasive clinical isolates of $C$. albicans. Stationary phase yeast cells of strains Ca30 and Ca94 were diluted 50 -fold with fresh YPD medium, grown at $30^{\circ} \mathrm{C}$ and samples were removed at various time-points. RNA was extracted, subjected to Northern blotting and hybridized to probes specific for CHS1, CHS2 and CHS3.

The pattern of CHS gene expression of strain 3153 was also compared to that of strain CA2 during hypha development. Strain CA2 is impaired in germ tube formation in vitro, but not in vivo (De Bernardis et al., 1993). When grown at low inoculation density under conditions that normally induce germ tube formation (Buffo et al., 1984), CA2 formed fewer than $5 \%$ germ tubes. Northern analysis indicated that $\mathrm{CaCHS1} \mathrm{mRNA}$ levels in CA2 were comparable to those of strain 3153 under conditions that would normally stimulate germ tube formation (Fig. 4). However, CaCHS2 and $\mathrm{CaCHS} 3$ expression increased more slowly in CA2 in these media and peaked $4 \mathrm{~h}$ after induction compared to 1-2 $\mathrm{h}$ after induction for germ-tube-positive strains. This transcriptional pattern differed from that in germtube-positive strains grown under hypha-inducing or -repressive conditions. Therefore, under all conditions tested a transient increase in the transcription of $\mathrm{CaCHS} 2$ and $\mathrm{CaCHS} 3$ was correlated with germ tube development.

\section{Chitin synthase activity during the dimorphic transition}

Chitin synthase activity, with and without trypsin pretreatment, was measured for germ-tube-positive (3153) and germ-tube-negative (CA2) strains (Fig. 5). Cells were grown in YPD for yeast growth and serumcontaining medium for hyphal cultures and under conditions employed previously for culture-densityregulated dimorphism. The pattern of chitin synthase activities of the two strains was similar but not predicted by the patterns of $\mathrm{CHS}$ gene expression. For example, at 


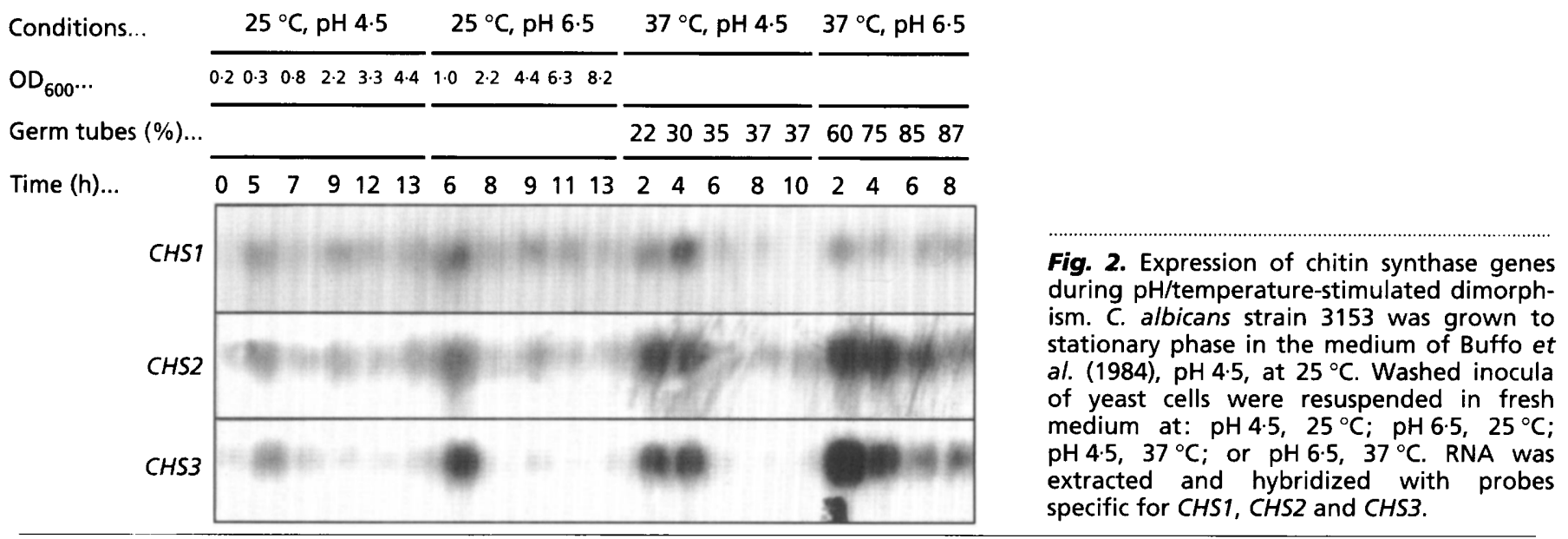

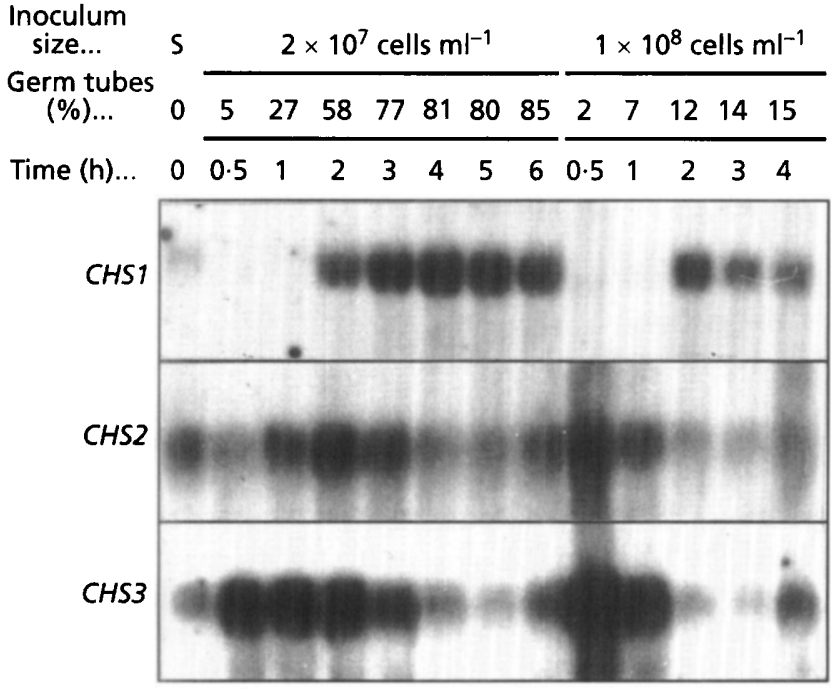

Fig. 3. Expression of chitin synthase genes during inoculumdensity-regulated dimorphism. C. albicans strain 3153 was grown in the medium of Buffo et al. (1984), $\mathrm{pH} 45$, at $25^{\circ} \mathrm{C}$ to stationary phase. Washed inocula of yeast cells were incubated in fresh medium at $\mathrm{pH} 6.5$ at $2 \times 10^{7}$ cells $\mathrm{ml}^{-1}$ or $1 \times 10^{8}$ cells $\mathrm{ml}^{-1}$ and incubated at $37^{\circ} \mathrm{C}$. Low inoculum density supported hypha formation whilst high inoculum density maintained growth mainly in the yeast form. RNA was extracted from cells harvested at different time-points up to $4 \mathrm{~h}$ and analysed by Northern blotting with probes specific for the three CHS genes. S, Stationary phase.

$2 \mathrm{~h}$ post hypha induction, the levels of $\mathrm{CaCHS} 2$ and $\mathrm{CaCHS} 3$ mRNA were markedly higher in strain 3153 compared to CA2. However, at this time-point the only difference in the chitin synthase activities was a slight decrease in the activity of CA2 prior to trypsin pretreatment. Cells grown in serum and YPD also had similar changes in chitin synthase activity in the two strains but activities were higher in these two media compared to the cells isolated from $\mathrm{pH} /$ temperatureregulated cultures (data not shown). Therefore, chitin synthase production must also be regulated at a posttranscriptional and/or post-translational level.

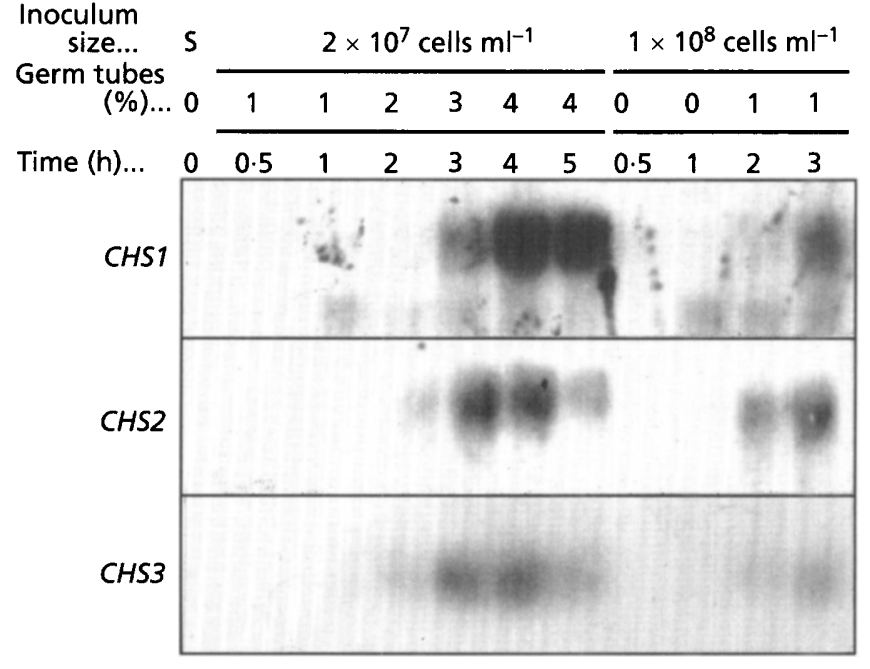

Fig. 4. Expression of $\mathrm{CHS}$ genes during growth of a nongerminative $C$. albicans strain, CA2, under conditions which stimulate germ tube induction in wild-type strains. A culture was grown to stationary phase in the medium of Buffo et al. (1984), $\mathrm{pH} 4.5$, at $25^{\circ} \mathrm{C}$ and then subcultured into fresh medium at $\mathrm{pH} 6.5$ and $37^{\circ} \mathrm{C}$ at either $2 \times 10^{7}$ cells $\mathrm{ml}^{-1}$ (conditions that would normally support germ tube formation) or $1 \times 10^{8}$ cells $\mathrm{ml}^{-1}$ (which maintained growth in the yeast form). RNA was extracted and subjected to Northern blot analysis with probes specific for the three CHS genes of C. albicans. S, Stationary phase.

\section{Chitin synthase activity of $\Delta$ chs 2 mutants}

The chitin synthase activity of the $\Delta c h s 2$ null mutant was reduced three- to fivefold compared to the SGY243 parent in both yeast and hyphal cells (Fig. 6). Strain SGY243 has three copies of the CaCHS2 gene (Gow et al., 1994). Progressive decreases in total chitin synthase activity were observed in strains harbouring one, two or three disrupted copies of the $\mathrm{CaCHS} 2$ gene. The residual $20 \%$ chitin synthase activity in the $\Delta c h s 2$ null mutant presumably corresponds to $\mathrm{CaChs} 1 \mathrm{p}$ and $\mathrm{CaChs} 3 \mathrm{p}$ activities. Chitin synthase activities were compared 


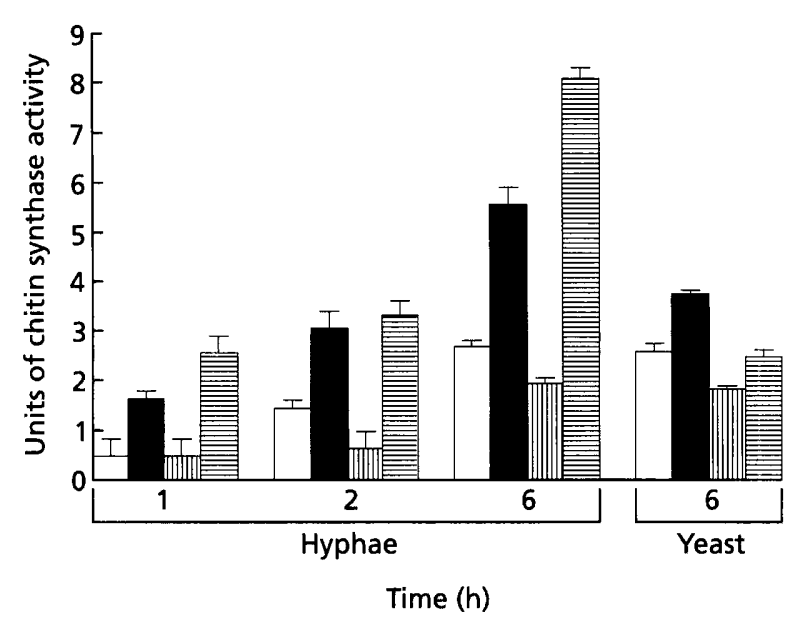

Fig. 5. Measurement of chitin synthase activity in strain 3153 and the non-germinative strain CA2. Stationary phase yeast

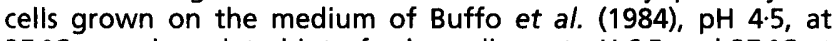
$25^{\circ} \mathrm{C}$ were inoculated into fresh medium at $\mathrm{pH} 6.5$ and $37^{\circ} \mathrm{C}$ at an inoculum density of $2 \times 10^{7}$ cells $\mathrm{ml}^{-1}$ (low density for hyphal growth) or $\geqslant 1 \times 10^{8}$ cells $\mathrm{ml}^{-1}$ (high density for yeast growth). Cells were harvested at 1, 2 and $6 \mathrm{~h}$ time-points and MMFs were prepared. The total chitin synthase activity of each membrane fraction was measured as described in Methods. Errors bars are SD $(n=3)$. $\square, 3153 ; \square, 3153$ plus trypsin; 皿, CA2; 圆, CA2 plus trypsin.

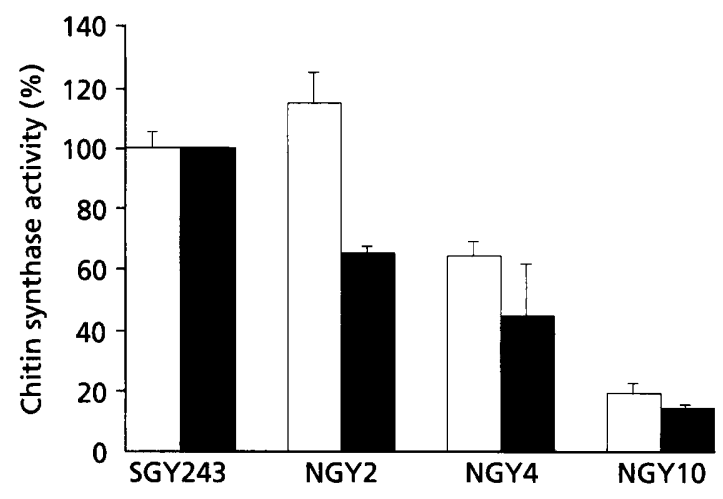

Fig. 6. Measurement of chitin synthase activity of $\Delta$ chs 2 mutants compared to their parental strain SGY243. Strains NGY2, NGY4 and NGY10 have one, two and three copies of the CHS2 gene disrupted, respectively. The activities were measured after trypsin pre-treatment and the activities of SGY243 membrane preparations from yeast and hyphal cells were taken as $100 \%$. For strain SGY243, hyphal membranes had approximately twofold higher activity than yeast membranes. Representative data from one of three independent experiments are presented. Mean values from independent treatments were not significantly different $(P<0.05)$. Error bars are SD $(n=3)$. $\square$, Yeast; $\square$, hyphae.

when $\mathrm{Co}^{2+}$ replaced $\mathrm{Mg}^{2+}$ in the assay (Table 2). There was little difference in the level of the total activity in wild-type cells, although the trypsinized membranes gave slightly higher activity with $\mathrm{Mg}^{2+}$ whereas the untreated membranes had higher activity in the presence of $\mathrm{Co}^{2+}$. Trypsinized membranes from the $\Delta c h s 2$ null mutant also had marginally increased activity in the presence of $\mathrm{Co}^{2+}$, suggesting that $\mathrm{CaChs} 1 \mathrm{p}$ and $\mathrm{CaChs} 3 \mathrm{p}$ may be activated preferentially by $\mathrm{Co}^{2+}$ while $\mathrm{CaChs} 2 \mathrm{p}$ is most efficiently activated by $\mathrm{Mg}^{2+}$. The differences in activities with $\mathrm{Mg}^{2+}$ and those with $\mathrm{Co}^{2+}$ were not statistically significant $(P<0 \cdot 05)$. The inhibition of the chitin synthase activity by a mixture of nikkomycins $X$ and $\mathrm{Z}$ was compared for membranes from SGY243 and the $\Delta$ chs 2 null mutant (Table 2). In wild-type membranes, chitin synthase activity was decreased by $70 \%$ in the presence of $2.5 \mu \mathrm{M}$ nikkomycin whereas $50 \mu \mathrm{M}$ nikkomycin was required to reduce the chitin synthase activity of the $\Delta c h s 2$ null mutant by $70 \%$.

\section{Measurement of chitin contents}

The chitin content of the cell wall of yeast and hyphal forms of strain SGY243 and the $\Delta c h s 2$ null strain NGY10 was determined using three chitin content assays (Fig. 7). The nitrous acid method (Ride \& Drysdale, 1972) gave similar values for the chitin content of yeast cells of both strains with only marginally elevated values for $\Delta c h s 2$ yeast cells. The value for the chitin content of the hyphal form of SGY243 was double that of the chitin content of the yeast form whereas hyphae of the $\Delta c h s 2$ null mutant contained about the same amount of chitin as the yeast form. As reported previously, the hyphal form of the $\Delta c h s 2$ null mutant had a $44 \%$ reduction in chitin content compared to the wild-type strain (Gow et al., 1994). However, when chitin content was determined by measuring glucosamine released by acid hydrolysis (Yabe et al., 1996) the $\Delta c h s 2$ null mutant showed elevated chitin levels in the yeast form, and there was no significant difference in the chitin content of hyphae in parental and $\Delta c h s 2$ null strains. A third chitin content assay in which the $\mathrm{N}$-acetylglucosamine released from chitin by the action of chitinase and $\beta$ - $N$-acetylhexosaminidase was measured (Bulawa et al., 1995) gave similar results to those obtained by acid hydrolysis but yielded much lower chitin contents than the previous two methods (Fig. 7). The parental and $\Delta c h s 2$ mutant strains had similar chitin contents and there was no appreciable increase in the amount of chitin in the hyphal forms. Pre-treating cells with lyticase (Sigma) or Zymolyase-20T (ICN Biomedicals) to digest $\beta$-glucans that may have been covalently attached to the chitin did not increase the amount of $\mathrm{N}$-acetylglucosamine released by this method.

The chitin content of the $\Delta c h s 3$ null mutant of $C$. albicans was also measured using the three chitin assays. The Ride \& Drysdale (1972) and the acid hydrolysis protocols both showed that the yeast and hyphae of the $\Delta c h s 3$ null mutant had $32-39 \%$ of the chitin content of the parental strain CAI4, comparable to the $60 \%$ reduction in chitin content reported by Mio et al. (1996), measured using the acid hydrolysis method. Chitin determination by the enzymic method gave an $85 \%$ reduction in both yeast and hyphae which is again 
Table 2. Chitin synthase activities measured in the presence of $\mathrm{Mg}^{2+}, \mathrm{Co}^{2+}$ and nikkomycins $X$ and $Z$

Results are expressed as units of chitin synthase activity. One unit represents 1 nmol UDP- $N$ acetylglucosamine incorporated into chitin $\min ^{-1}$ (mg protein $)^{-1}$.

\begin{tabular}{|c|c|c|c|c|}
\hline \multirow[t]{2}{*}{ Strain } & \multirow[t]{2}{*}{ Trypsin } & \multicolumn{3}{|c|}{ Chitin synthase activity in the presence of: } \\
\hline & & $\mathrm{Mg}^{2+*}$ & $\mathrm{Co}^{2+*}$ & Nikkomycin $(\boldsymbol{\mu} \mathbf{M}) \dagger$ \\
\hline $\begin{array}{l}\text { SGY243 } \\
\text { (wild-type) }\end{array}$ & $\begin{array}{l}- \\
+\end{array}$ & $\begin{array}{l}3 \cdot 0 \pm 1 \cdot 0 \\
7 \cdot 6 \pm 0 \cdot 7\end{array}$ & $\begin{array}{l}4.0 \pm 0.7 \\
5.8 \pm 1 \cdot 6\end{array}$ & $\begin{array}{l}7 \cdot 2 \pm 1 \cdot 4(0 \cdot 0) \\
2 \cdot 1 \pm 0 \cdot 6(2 \cdot 5) \\
1 \cdot 4 \pm 0 \cdot 4(10 \cdot 0)\end{array}$ \\
\hline NGY10 ( $\Delta c h s 2)$ & $\overline{+}$ & $\begin{array}{l}1 \cdot 0 \pm 0.5 \\
1 \cdot 4 \pm 0.3\end{array}$ & $\begin{array}{l}1.4 \pm 0.5 \\
1.7 \pm 0.8\end{array}$ & $\begin{array}{l}0 \cdot 9 \pm 0.1(0 \cdot 0) \\
0 \cdot 7 \pm 0 \cdot 1(10 \cdot 0) \\
0 \cdot 3 \pm 0 \cdot 1(50 \cdot 0)\end{array}$ \\
\hline
\end{tabular}

"Each value represents the mean \pm SD of triplicate samples measured from three independent experiments.

† Trypsin-activated yeast MMFs were used for measurement of chitin synthase activity and the assay was performed in the presence of magnesium. Values represent the mean \pm SD of triplicate samples.

similar to previous examination of yeast cells of the Candida $\Delta$ chs 3 mutant using this method (Bulawa et al., 1995). Therefore we conclude that the apparent disparities in the published literature on chitin contents of various CHS null mutants reflect differences in the methods used for chitin determinations.

One notable difference between the three assays was their ability to break down ultrapure crystalline chitin (Katakura Chikkarin). The Ride \& Drysdale (1972) method detected only $28 \%$ and the acid hydrolysis method $60 \%$, while the enzymic method was unable to break down crystalline chitin at all.

\section{DISCUSSION}

We have characterized the expression pattern of the three genes encoding chitin synthase isoenzymes in $C$. albicans, and the relative contribution of the isoenzymes to enzyme activity in vitro and chitin formation through an analysis of strains with specific null mutations. Northern analyses of the three chitin synthase genes of C. albicans described here and previously (Chen-Wu et al., 1992; Sudoh et al., 1993) showed that they were regulated differentially at the transcriptional level. Previous reports of $\mathrm{CHS}$ gene expression in C. albicans found elevated levels of $\mathrm{CaCHS} 2$ and $\mathrm{CaCHS} 3 \mathrm{mRNA}$ in hyphal cells and a preference for $\mathrm{CaCHS1}$ expression in yeast cells (Chen-Wu et al., 1992; Sudoh et al., 1993). However, in this more expansive study we found CaCHS1 was expressed equally in yeast and hyphal cells. CaCHS1 expression exhibited a different pattern to that of $\mathrm{CaCHS} 2$ and $\mathrm{CaCHS3}$. Highest levels of CaCHS1 mRNA occurred in the late exponential phase of yeast phase growth. CaCHS2 and CaCHS3 were coexpressed and exhibited a transient peak of expression 1-2 $\mathrm{h}$ after induction of the hyphal growth phase under all the conditions tested. Levels then subsided by $4 \mathrm{~h}$ of hyphal induction. The elevated level of $\mathrm{CaCHS} 2$ and
CaCHS3 mRNA in hyphal cells is commensurate with hyphal cells having a higher chitin content and chitin synthase activity than yeast cells. However, both the $\Delta c h s 2$ and $\Delta c h s 3$ null mutants formed hyphae efficiently and in wild-type cells the elevated chitin content of hyphal cells was maintained even when $\mathrm{CaCHS} 2$ and CaCHS 3 mRNA levels declined. Therefore these genes are not required for hypha formation and the temporal pattern of transcription does not tightly parallel the extent of chitin synthesis. Under conditions that normally induced filamentous growth, the non-germinative strain CA2 did not show the initial stimulation of $\mathrm{CaCHS} 2$ and $\mathrm{CaCHS} 3$ expression observed in germtube-competent strains. However, total chitin synthase activity (mostly due to CaChs $2 \mathrm{p}$ activity) increased in a similar way to that seen in the wild-type strain 3153 . This again underlines the general conclusion that there was no overt relationship between up-regulated $\mathrm{CHS}$ gene expression and changes in chitin synthase activity, chitin content and cell shape.

Measurement of chitin synthase activity of the $\Delta c h s 2$ null mutant showed that CaChs $2 p$ is the major activity when assayed in vitro. Previous reports of zymogenic chitin synthase activity measured in wild-type cells can therefore be contributed in the main to $\mathrm{CaChs} 2 \mathrm{p}$ activity since this dominant activity will normally mask the other enzymes. In $S$. cerevisiae, the Chs1p activity was responsible for most activity in vitro (Bulawa et al., 1986). The chitin synthase activity remaining in the Candida $\Delta$ chs 2 null mutant had a preference for $\mathrm{Co}^{2+}$ over $\mathrm{Mg}^{2+}$ in both untreated and trypsin-treated membranes, whereas the native zymogenic activity encoded by $\mathrm{CaCHS} 2$ was maximal in the presence of $\mathrm{Mg}^{2+}$. The Candida Chs2p and the Saccharomyces Chs1p share the properties of having the highest total in vitro activity and similar metal ion requirements. In addition, the activity remaining in the Candida $\Delta c h s 2$ null mutant was 

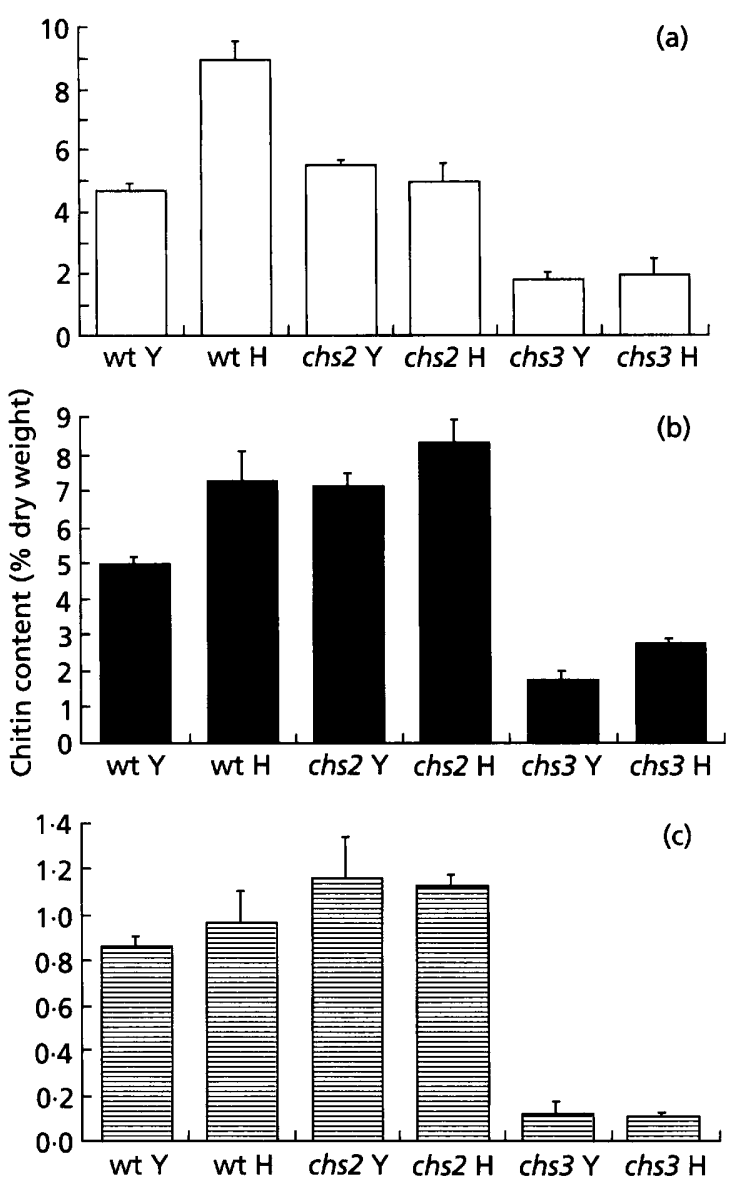

Fig. 7. Chitin content of C. albicans strains SGY243 and the $\Delta$ chs2 null mutant NGY10 were measured following three protocols: (a) the nitrous acid method of Ride \& Drysdale (1972); (b) the acid hydrolysis method (Yabe et al., 1996); and (c) the chitinase extraction method (Bulawa et al., 1986). The chitin contents of at least three independent cultures were measured using each method. Assays were performed a minimum of three times and each sample was measured in triplicate. The means from independent cultures were not significantly different $(P<0.05)$. Error bars represent \pm SE. $Y$, Yeast; $H$, hyphae; wt, wild-type.

much more resistant to nikkomycin compared to the CaChs2p activity. In S. cerevisiae, ScChs1p is the most sensitive to nikkomycin while ScChs $2 p$ is least sensitive (Gaughran et al., 1994). These observations coupled with evidence from deduced protein sequences (ChenWu et al., 1992) again suggest that the CaCHS2 gene product is more closely related to the ScCHS1 gene product than to the Saccharomyces Chs2p.

In wild-type strains, chitin synthase activity increased steadily up to $6 \mathrm{~h}$ after germ tube induction. The activity measurements did not parallel the mRNA levels, which were highest for $\mathrm{CaCHS} 2$ and $\mathrm{CaCHS} 3 \mathrm{1}-2 \mathrm{~h}$ after the switch to hyphal growth. This may indicate regulation at the post-transcriptional level and may reflect in part the relative stability of the chitin synthase isoenzymes (Chuang \& Schekman, 1996; Ziman et al., 1996). In S. cerevisiae, Choi et al. (1994a) showed that post-trans- lational regulation of $S c C H S 1$ and $S c C H S 3$ appeared to be predominant over translational regulation, whereas ScCHS2 was apparently regulated both at the transcriptional level and by synthesis and degradation of the gene product. There are many possible post-transcriptional regulatory processes that can modulate chitin synthesis (Gooday, 1995; Gooday \& Schofield, 1995; Munro \& Gow, 1995). These include provision of substrate, allosteric activation of chitin synthase, phosphorylation, dephosphorylation, modulation of the assembly of the chitin chains in the cell, activation of zymogenicity and in the case of Chs $3 p$ regulation by other proteins of a multienzyme complex including homologues of ScChs4p (Csd4p/Cal2p) and ScChs5p (Cal3p) (Bulawa, 1993; Santos et al., 1997; Trilla et al., 1997).

The insolubility and chemical resistance of chitin make quantitative determinations of chitin content difficult. Measurement of chitin in C. albicans has given a wide range of values in the past. Chattaway et al. (1968) measured chitin contents of around 3\% for the alkaliinsoluble fraction of yeast cell walls and $10 \%$ for the same fraction isolated from hyphae, whereas Sullivan $e t$ al. (1983) estimated the chitin content of isolated cell walls on a dry weight basis to be $0.6 \%$ for yeast and $2.7 \%$ for hyphae. Elorza et al. (1994) determined that chitin constituted $10 \%$ of wall polysaccharides in yeast cells and $21.6 \%$ in hyphae. These figures are difficult to compare with the results presented here, which were measured in extractions of whole cells. Chitin is in the innermost layer of the fungal cell wall and is masked by and covalently linked to other components of the wall, including mannoproteins and (1-3)- $\beta$ - and (1-6)- $\beta$ glucan (Klis, 1994). Methods used to extract and assay chitin rely on chemical or enzymic treatments to strip off these outer layers, exposing the chitin fibrils. The method of Ride \& Drysdale (1972) uses strong alkali to deacetylate chitin to chitosan. The total glucosamine method relies on acid hydrolysis to depolymerize chitin to glucosamine (Yabe et al., 1996). Acid hydrolysis also liberates glucosamine from glycoproteins, which could lead to overestimation of chitin content. Prolonged hydrolysis can also result in loss of hexosamines. Chitinase extraction methods (e.g. Bulawa et al., 1986) have the virtue of specificity for chitin but we found that this method gave around a threefold lower chitin content than the other two methods we investigated. However, the results from the first two methods were corrected by factors which gave a $100 \%$ yield of crystalline chitin and the chitinase method was not corrected in this fashion. This enzymic method consistently failed to demonstrate an increase in the chitin content of hyphal cells compared to yeasts as has been observed using chemical extraction methods (Chattaway et al., 1968; Sullivan et al., 1983; Gow et al., 1994).

Chitin present in the different regions of the fungal cell wall may also vary in its crystallinity and the degree of cross-linking to other components of the cell wall, e.g. (1-3)- $\beta$-glucans (Wessels, 1986). Crystalline chitin is more resistant to degradation by chitinases (Vermeulen 
$\&$ Wessels, 1984). Indeed the enzymes used here were unable to break down crystalline chitin whereas the Ride \& Drysdale (1972) method detected $28 \%$ and the acid hydrolysis method $60 \%$ of crystalline chitin. Assante et al. (1996) also obtained only a $20 \%$ yield of purified chitin when using a modified version of the Ride $\&$ Drysdale (1972) method in which chitin was deacetylated with $4 \mathrm{M} \mathrm{KOH}$ at $130^{\circ} \mathrm{C}$. However, acid hydrolysis followed by deamination with nitrous acid achieved an almost quantitative yield and this method is probably worth considering for future experiments. The failure of chitinase to extract all the chitin in yeast and hyphal cell walls may therefore reflect the extent of chitin crystallinity and cross-linking with other polysaccharides and proteins, although we found that pretreatment of Candida cell walls with lyticase and Zymolyase did not increase the extraction of $\mathrm{N}$ acetylglucosamine by chitinase.

The measurement of chitin may also be complicated by the presence of significant amounts of chitosan in the cell wall. Chitosan would be broken down by the Ride \& Drysdale (1972) method but not by the enzymic assay. Preliminary examinations revealed only small quantities of chitosan in C. albicans $(0.2 \%$ of dry cell weight) and equal amounts were detected in yeast and hyphae (data not shown). Therefore, the presence of chitosan is unlikely to be the cause of the anomalous chitin contents.

Previously the chitin content of the $\Delta c h s 2$ null mutant had been reported to be reduced by $40 \%$ in the hyphal form (Gow et al., 1994). More recently, Mio et al. (1996) reported a much smaller decrease in hyphal chitin content in this mutant. This anomaly can be explained by the differences in the two methods used to measure chitin. This study showed that the hyphal chitin content of $\Delta c h s 2$ was reduced by $\sim 44 \%$ compared to the parental strains when chitin contents were determined by the Ride \& Drysdale (1972) method employed by Gow et al. (1994). However, little difference was seen when measured by the acid hydrolysis method used by Mio et al. (1996). Interestingly, all three methods gave elevated chitin levels in the yeast form of the $\Delta c h s 2$ null mutant compared to the parental strain. This could be explained by an increase in activity of one or both of the other isoenzymes to compensate for loss of CaChs $2 \mathrm{p}$; however, such an increase in activity was not detected (data not shown). Each of the methods also gave a consistently lower chitin content for the $\Delta c h s 3$ null mutant. Our results underline the point that chitin determinations are highly dependent on the method employed and that the apparent chitin contents inferred from extractions of cell wall material isolated from chs null mutant strains must be interpreted cautiously.

Measurement of total chitin synthase activity as reported here has also shown that $\mathrm{CaCHS} 2$ encodes the major chitin synthase activity when assayed in vitro and the two- to threefold increase in chitin synthase activity seen in the hyphal form was also due mainly to the CaChs $2 \mathrm{p}$ enzyme. By analogy with $S$. cerevisiae, $\mathrm{CaChs} 2 \mathrm{p}$ may act in a similar way to ScChs1p, functioning as a repair enzyme during the separation of the mother and bud cell (Cabib et al., 1992). However, we have shown that $\mathrm{CaCHS} 2$ is expressed preferentially in the hyphal form where cell division is not accompanied by cell separation, and that $\Delta c h s 2$ mutants may have a reduced chitin content in the hyphal form. Therefore, $\mathrm{CaCHS2}$ may have an additional role to play in the hyphal form of C. albicans, e.g. it may be involved in maintaining cell wall integrity during branching, which may involve wall-softening by chitinases (Gooday et al., 1992). However, there was no evidence of abnormal branching in the $\Delta c h s 2$ mutant. We did not observe the bud lysis phenotype described in $\Delta c h s 1$ mutants in S. cerevisiae (Bulawa et al., 1986), even under conditions where the $\mathrm{pH}$ of the medium was adjusted to maximize the potentially damaging activities of chitinases which, in $S$. cerevisiae, play a role in bud separation and require subsequent chitin repair by ScChs1p (Cabib et al., 1992).

Our results indicate that CaChs3p is the dominant chitin-synthesizing enzyme in both yeasts and hyphae of C. albicans, but that CaChs $2 p$ plays a minor role in chitin formation in the lateral cell walls of hyphae.

\section{ACKNOWLEDGEMENTS}

This work was supported by the award of BBSRC studentships to C.A.M. and D.A.S., and grants from The Wellcome Trust (039643/Z/93/JRS/RF) and BBSRC (CEL04556). We thank Bernie Hube, Garry Cole, Antonio Cassone, Rosemarie Kelly and Christine Bulawa for the provision of strains.

\section{REFERENCES}

Assante, G., Carelli, A., Carzniga, R., Farina, G. \& Gozzo, F. (1996). Changes in chitin and chitosan content of Ustilago maydis DC (Corda) induced by tetraconazole. In Chitin Enzymology, pp. 459-477. Edited by R. A. A. Muzzarelli. Grottammare, Italy: Atec Edizioni.

Au-Young, J. \& Robbins, P. W. (1990). Isolation of a chitin synthase gene (CHS1) from Candida albicans by expression in Saccharomyces cerevisiae. Mol Microbiol 4, 197-207.

Bowen, A. R., Chen-Wu, J. L., Momany, M., Young, R., Szaniszlo, P. J. \& Robbins, P. W. (1992). Classification of fungal chitin synthases. Proc Natl Acad Sci USA 89, 519-523.

Braun, P. C. \& Calderone, R. A. (1978). Chitin synthesis in Candida albicans: comparison of yeast and hyphal forms. J Bacteriol $\mathbf{1 3 5}$, 1472-1477.

Buffo, J., Herman, M. A. \& Soll, D. R. (1984). A characterization of $\mathrm{pH}$-regulated dimorphism in Candida albicans. Mycopathologia 85, 21-30.

Bulawa, C. E. (1992). CSD2, CSD3, and CSD4, genes required for chitin synthesis in Saccharomyces cerevisiae: the CSD2 gene product is related to chitin synthases and to developmentally regulated proteins in Rhizobium species and Xenopus laevis. Mol Cell Biol 12, 1764-1776.

Bulawa, C. E. (1993). Genetics and molecular biology of chitin synthesis in fungi. Annu Rev Microbiol 47, 505-534.

Bulawa, C. E. \& Osmond, B. C. (1990). Chitin synthase I and chitin synthase II are not required for chitin synthesis in vivo in Saccharomyces cerevisiae. Proc Natl Acad SciUSA 87, 7424-7428. 
Bulawa, C. E., Slater, M., Cabib, E., Au-Young, J., Sburlati, A., Adair, W. L. \& Robbins, P. W. (1986). The $S$. cerevisiae structural gene for chitin synthase is not required for chitin synthesis in vivo. Cell 46, 213-225.

Bulawa, C. E., Miller, D. W., Henry, L. K. \& Becker, J. M. (1995). Attenuated virulence of chitin-deficient mutants of Candida albicans. Proc Natl Acad Sci USA 92, 10570-10574.

Cabib, E., Sburlati, A., Bowers, B. \& Silverman, S. J. (1989). Chitin synthase 1, an auxiliary enzyme for chitin synthesis in Saccharomyces cerevisiae. J Cell Biol 108, 1665-1672.

Cabib, E., Silverman, S. J. \& Shaw, J. A. (1992). Chitinase and chitin synthase 1 : counterbalancing activities in cell separation of Saccharomyces cerevisiae. J Gen Microbiol 138, 97-102.

Chattaway, F. W., Holmes, M. R. \& Barlow, A. J. E. (1968). Cell wall composition of the mycelial and blastospore forms of Candida albicans. J Gen Microbiol 51, 367-376.

Chen-Wu, J. L., Zwicker, J., Bowen, A. R. \& Robbins, P. W. (1992). Expression of chitin synthase genes during yeast and hyphal growth phases of Candida albicans. Mol Microbiol 6, 497-502.

Choi, W. J., Santos, B., Duran, A. \& Cabib, E. (1994a). Are yeast chitin synthases regulated at the transcriptional or the posttranslational level? Mol Cell Biol 14, 7685-7694.

Choi, W. J., Sburlati, A. \& Cabib, E. (1994b). Chitin synthase 3 from yeast has zymogenic properties that depend on both the CAL1 and the CAL3 genes. Proc Natl Acad Sci USA 91, 4727-4730.

Chuang, J. S. \& Schekman, R. (1996). Differential trafficking and timed localization of two chitin synthase proteins, Chs2p and Chs3p. J Cell Biol 135, 597-610.

Cole, G. T., Lynn, K. T. \& Seshan, K. R. (1990). An animal model for oropharyngeal, esophageal and gastric candidosis. Mycoses 33, 7-19.

De Bernardis, F., Adriani, F. D., Lorenzini, R., Pontieri, E., Carruba, G. \& Cassone, A. (1993). Filamentous growth and elevated vaginopathic potential of a non-germinative variant of Candida albicans expressing low virulence in systemic infection. Infect Immun 61, 1500-1508.

Delbruck, S. \& Ernst, J. F. (1993). Morphogenesis-independent regulation of actin transcript levels in the pathogenic yeast Candida albicans. Mol Microbiol 10, 859-866.

Din, A. B., Specht, C. A., Robbins, P. W. \& Yarden, O. (1996). chs4, a class IV chitin synthase gene from Neurospora crassa. Mol Gen Genet 250, 214-222.

Elorza, M. V., Sentandreu, R. \& Ruiz-Herrera, J. (1994). Isolation and characterization of yeast monomorphic mutants of Candida albicans. J Bacteriol 176, 2318-2325.

Gaughran, J. P., Lai, M. H., Kirsch, D. R. \& Silverman, S. J. (1994). Nikkomycin $\mathrm{Z}$ is a specific inhibitor of Saccharomyces cerevisiae chitin synthase isozyme Chs 3 in vitro and in vivo. J Bacteriol 176, 5857-5860.

Georgiev, O. I., Nikolaev, N., Hadjiolov, A. A., Skryabin, G., Zakharyev, V. M. \& Bayev, A. A. (1981). The structure of the yeast ribosomal RNA genes. 4. Complete sequence of the $25 \mathrm{~S}$ rRNA gene from Saccharomyces cerevisiae. Nucleic Acids Res 9, 6953-6958.

Gooday, G. W. (1995). The dynamics of hyphal growth. Mycol Res 99, 385-394.

Gooday, G. W. \& Schofield, D. A. (1995). Regulation of chitin synthesis during growth of fungal hyphae - the possible participation of membrane stress. Can J Bot 73 (Suppl. 1), S114-S121.
Gooday, G. W., Zhu, W. Y. \& O'Donnell, R. W. (1992). What are the roles of chitinases in the growing fungus? FEMS Microbiol Lett 100, 387-391.

Gow, N. A. R. \& Gooday, G. W. (1982). Vacuolation, branch production and linear growth of germ tubes of Candida albicans. J Gen Microbiol 128, 2195-2198.

Gow, N. A. R., Robbins, P. W., Lester, J. W., Brown, A. J. P., Fonzi, W. A., Chapman, T. \& Kinsman, O. (1994). A hyphal-specific chitin synthase gene (CHS2) is not essential for growth, dimorphism, or virulence of Candida albicans. Proc Natl Acad Sci USA 91, 6216-6220.

Gow, N. A. R., Hube, B., Bailey, D. \& 9 other authors (1995). Genes associated with dimorphism and virulence of Candida albicans. Can J Bot 73 (Suppl. 1), S335-S342.

Hill, J. E., Myers, A. M., Koerner, T. J. \& Tzagoloff, A. (1986). Yeast/E. coli shuttle vectors with multiple unique restriction sites. Yeast 2, 163-167.

Hube, B., Monod, M., Schofield, D. A., Brown, A. J. P. \& Gow, N. A. R. (1994). Expression of seven members of the gene family encoding secretory aspartyl proteinases in Candida albicans. Mol Microbiol 14, 87-99.

Kelly, R., Miller, S. M., Kurtz, M. B. \& Kirsch, D. R. (1987). Directed mutagenesis in Candida albicans: one-step gene disruption to isolate ura3 mutants. Mol Cell Biol 7, 199-208.

Klis, F. M. (1994). Review : Cell wall assembly in yeast. Yeast 10, 851-869.

Lee, K. L., Buckley, H. R. \& Campbell, C. C. (1975). An amino acid liquid synthetic medium for the development of mycelial and yeast forms of Candida albicans. Sabouraudia 13, 148-153.

Mellado, E., Aufauvre-Brown, A., Gow, N. A. R. \& Holden, D. W. (1996). The Aspergillus fumigatus chs $C$ and $c h s G$ genes encode Class III chitin synthases with different functions. Mol Microbiol 20, 667-679.

Mio, T., Yabe, T., Sudoh, M., Satoh, Y., Nakajima, T., Arisawa, M. \& Yamada-Okabe, H. (1996). Role of three chitin synthase genes in the growth of Candida albicans. J Bacteriol 178, 2416-2419.

Munro, C. A. \& Gow, N. A. R. (1995). Chitin biosynthesis as a target for antifungals. In Antifungal Agents: Discovery and Mode of Action, pp. 161-171. Edited by G. K. Dixon, L. G. Copping \& D. W. Hollomon. Oxford: Bios Scientific.

Orlean, P. (1987). Two chitin synthases in Saccharomyces cerevisiae. J Biol Chem 262, 5732-5739.

Ride, J. P. \& Drysdale, R. B. (1972). A rapid method for the chemical estimation of filamentous fungi in plant tissue. Physiol Plant Pathol 2, 7-15.

Rubtsov, P. M., Musakhanov, M. M., Zakharyev, V. M., Krayer, V. M., Skryabin, G. \& Bayev, A. A. (1980). The structure of the yeast ribosomal RNA genes. I. The complete nucleotide sequence of the $18 \mathrm{~S}$ ribosomal RNA gene from Saccharomyces cerevisiae. Nucleic Acids Res 8, 5779-5794.

Santos, B., Duran, A. \& Valdivieso, M. H. (1997). CHS5, a gene involved in chitin synthesis \& mating in Saccharomyces cerevisiae. Mol Cell Biol 17, 2485-2496.

Semino, C. E. \& Robbins, P. W. (1995). Synthesis of 'Nod'-like chitin oligosaccharides by the Xenopus developmental protein DG42. Proc Natl Acad Sci USA 92, 3498-3501.

Shaw, J. A., Mol, P. C., Bowers, B., Silverman, S. J., Valdivieso, M. H., Duran, A. \& Cabib, E. (1991). The function of chitin synthases 2 and 3 in the Saccharomyces cerevisiae cell cycle. J Cell Biol 114, 111-123. 
Sherman, F. (1991). Getting started with yeast. Methods Enzymol 194, 3-21.

Silverman, S. J., Sburlati, A., Slater, M. \& Cabib, E. (1988). Chitin synthetase 2 is essential for septum formation and cell division in Saccharomyces cerevisiae. Proc Natl Acad Sci USA 85, 4735-4739.

Simonetti, N., Striploi, V. \& Cassone, A. (1974). Yeast-mycelial conversion induced by $N$-acetyl-D-glucosamine in Candida albicans. Nature 250, 344-346.

Sudoh, M., Nagahashi, S., Doi, M., Ohta, A., Takagi, M. \& Arisawa, M. (1993). Cloning of the chitin synthase 3 gene from Candida albicans and its expression during yeast-hyphal transition. Mol Gen Genet 241, 351-358.

Sullivan, P. A., Yin, C. Y., Molloy, C., Templeton, M. D. \& Shepherd, M. G. (1983). An analysis of the metabolism and cell wall composition of Candida albicans during germ tube formation. Can J Microbiol 29, 1514-1525.

Swoboda, R. K., Bertram, G., Colthurst, D. R., Tuite, M. F., Gow, N. A. R., Gooday, G. W. \& Brown, A. J. P. (1994). Regulation of the gene encoding translation factor 3 during growth and morphogenesis in Candida albicans. Microbiology 140, 26112616.

Trilla, J. A., Cos, T., Duran, A. \& Roncero, C. (1997). Characterization of CHS4 (CAL2), a gene of Saccharomyces cerevisiae involved in chitin biosynthesis and allelic to SKT5 and CSD4. Yeast 13, 795-807.
Valdivieso, M. H., Mol, P. C., Shaw, J. A., Cabib, E. \& Duran, A. (1991). CAL1, a gene required for activity of chitin synthase 3 in Saccharomyces cerevisiae. J Cell Biol 114, 101-109.

Vermeulen, C. A. \& Wessels, J. G. H. (1984). Ultrastructural differences between wall apices of growing and non-growing hyphae of Schizophyllum commune. Protoplasma 120, 123-131.

Wessels, J. G. H. (1986). Cell wall synthesis in apical hyphal growth. Int Rev Cytol 104, 37-79.

Yabe, T., Yamada-Okabe, T., Kasahara, S., Furuichi, Y., Nakajima, T., Ichishima, E., Arisawa, M. \& Yamada-Okabe, H. (1996). HKR1 encodes a cell surface protein that regulates both cell wall $\beta$ glucan synthesis and budding pattern in the yeast Saccharomyces cerevisiae. J Bacteriol 178, 477-483.

Yarden, O. \& Yanofsky, C. (1991). Chitin synthase 1 plays a major role in cell wall biogenesis in Neurospora crassa. Genes Dev $\mathbf{5}$, $2420-2430$

Ziman, M., Chuang, J. S., Schekman, R. \& Schekman, R. W. (1996). Chs1p and Chs3p, 2 proteins involved in chitin synthesis, populate a compartment of the Saccharomyces cerevisiae endocytic pathway. Mol Biol Cell 7, 1909-1919.

Received 10 June 1997; revised 20 September 1997; accepted 8 October 1997. 